\title{
Evaluation of the Boletín Médico del Hospital Infantil de México by the Literature Selection Technical Review Committee of the National Library of Medicine
}

\author{
Evaluación del Boletín Médico del Hospital Infantil de México por el Comité de Revisión \\ Técnica para Selección de la Literatura de la Biblioteca Nacional de Medicina
}

\section{María Guadalupe Campos-Lara*}

Editor-in-Chief, Boletín Médico del Hospital Infantil de México; certified by the University of Chicago, USA; graduated from the Publishing Training Center, London, England; International member in the editorial offices of the Journal of the American Medical Association

Evaluate ...evaluate... Evaluation, among other definitions, means to "collect and systematically analyze information to determine the value or merit of what is done". To evaluate all human activity is inherent to the very nature of man. Governments, health, education, arts, institutions, organizations, companies are evaluated, and of course, the scientific activity of researchers, their projects, their papers, their "productivity" and even the journals where they publish their results. Why? What? How?

On November 7, 2017, an email to the Boletín Médico del Hospital Infantil de México (BMHIM) arrived, with an attached letter from the Associate Director of Operations of the National Library of Medicine of the United States with the subject BMHIM, in which the first paragraph said: "The National Library of Medicine (NLM) uses an NIH-chartered advisory committee, the Literature Selection Technical Review Committee (LSTRC), to recommend journals to be indexed for MEDLINE ${ }^{\circledR}$. At the recent LSTRC meeting, the committee recommended your journal for MEDLINE ${ }^{\oplus}$. MEDLINE ${ }^{\oplus}$ citations are indexed with NLM Medical Subject Headings $\left(\mathrm{MeSH}^{\oplus}\right)$ and other metadata, and are searchable as a subset of PubMed ${ }^{\oplus}$."

First, joy. Great joy! The gap opened in December 1993, the last time that BMHIM appeared in MEDLINE, was finally closed. Next, great news to the authorities of our institute, and to the personnel of the Medical Editions Department ...Immediately after, acknowledgement; later, reflection...

Acknowledgements to the authors who, since July 2014, and before, have sent their research to our journal. To the reviewers, who made possible one the main pillars of academic journals with their voluntary and professional work: the evaluation of the scientific content by external colleagues and peers of the field in question. To the members of the board and editorial committee that have collaborated with the BMHIM. To the authorities of the Hospital Infantil de México Federico Gómez, who have unconditionally supported the development of BMHIM. To the translators. To the editors. To the publishers that have believed in our work.

Reflections ...It is worth mentioning the following: what did the LSTRC evaluate from our journal? Strict compliance with the periodicity of the publication of the Spanish electronic version (ISSN 1665-1146), also available in English; the quality of the content of the articles including authors and institutions; the quality of the external peer review. Furthermore, that all ethical policies were met: declaration of conflicts of interest, animal and human rights, and informed consent when appropriate.

\section{Correspondence:}

*María Guadalupe Campos-Lara Email: bolmedhospinfantmex@gmail.com
Available online: 12-07-2018 Bol Med Hosp Infant Mex. 2018;75:5-6 
What are the immediate results of been indexed in PubMed ${ }^{\circledR}$ ? Almost 180 countries with an Internet connection of the 195 recognized in the UN. Visibility since January 1,2017 , and probably an increase in the citation of the published works in the BMHIM.

What are the immediate actions that need to be taken? By suggestion of the LSTRC, to open the doors to more collaborations with Latin American countries and not only to publish Mexican research; increase the rigor of the peer review process, as well as reduce the acceptance rate: everything converges on the papers' quality.

We are also satisfied that the BMHIM is indexed in the Scielo, Scopus, Emerging Sources Citation Index, DOAJ, Latindex, EMBASE, WorldCat and EBSCO, as well as the fact that BMHIM is an open access journal.

What are the next actions that must be taken? It would seem obvious to continue in the career of indexing academic journals: Journal Citation Reports, Research Gate, the future impact factors. Surely we will make an effort to benefit the authors and their curricular evaluations. However, this would be the answer to the procedural inertia in academic journals. The task that awaits editors responsible for the development of "their" journals is arduous and time-consuming: achieve indexation in the Web of Science and accumulate numerous citations in other prestigious journals, promote their authors and articles to an extensive audience. The classic Journal Impact Factor remains an important citation metric, although it is not the only one, and its validity is in question. There is currently doubt about when it is necessary, and if it has been appropriately used by institutions and governments as the measure of quality and priority of scientific work ${ }^{1}$. As a result, in recent years, the American Society for Cell Biology has issued the San Francisco DORA (Declaration On Research Assessment) to recognize the need to improve the different ways in which the results of scientific research are evaluated ${ }^{2}$. Shortly after, the League of European Research Universities adhered to this statement ${ }^{3}$.

Evaluate: Why? What? How? Evaluation has historically been constituted as an instrument of selection and control. With it, attempts are made to specify methods of individual control and its extension to methods of social control ${ }^{4}$.

\section{References}

1. Hong ST, Gasparyan AY. Celebrating the latest release on the journal impact factors: Thinking globally, acting locally. J Korean Med Sci. 2015;30:999-1000.

2. American Society for Cell Biology. (2012, December 16). San Francisco declaration on research assessment. Available at: http://am.ascb.org/ dora.

3. Philips M. Research universities and research assessment. Available at: https://www.leru.org/files/M Philips-LERU-launch.pptm.

4. Rosales M. Proceso evaluativo: evaluación sumativa, evaluación formativa y assesment su impacto en la educación actual. Congreso lberoamericano de Ciencia, Tecnología, Innovación y Educación. 2014: Article 662. Buenos Aires, Argentina. 